\title{
EFFECT OF MODIFIED HUMIC ACID (MHA) BINDER ON ROASTING BEHAVIOR OF MONGOLIAN "TUMURTEI" IRON ORE CONCENTRATE BRIQUETTES
}

\author{
Bayaraa Saraatanbazar, Ph.D. Student ( s. bayar9@gmai l .com) \\ Guang-hui Li, Professor (2667361847@qq.com)
}

School of Minerals Processing and Bioengineering, Central South University

(410083, China, Changsha, Hunan)

\begin{abstract}
There are two major groups of binder: organic and inorganic binder for agglomeration process for reduction, and sintering for steel production. In this work, effect of composite binder on roasting of Mongolian "Tumurtei" iron ore concentrate briquettes in ambient atmosphere was studied, aiming to clarify optimal parameters of roasting behavior with three different MHA binders for direct reduction. Lignite contains organic and inorganic substances, and according to many previous investigations, it can be raw material for extraction of composite binder. Pressed iron concentrate with MHA binder was subjected to oxidation and reduction process in the electrical furnace. The optimum conditions of experiments were as follows. Parameters of briquetting process were carried out according to the no-binder briquetting test $0.75 \mathrm{t} \cdot \mathrm{cm}^{-2}$ pressure, 5 seconds pressing time, $8 \%$ of moisture content, oxidation at $950{ }^{\circ} \mathrm{C}$ under air flow for $10 \mathrm{~min}$, and reduction at $1100{ }^{\circ} \mathrm{C}$ under $\mathrm{CO}$ atmosphere. As a result, MHA binder extracted from "Baganuur" lignite affected the reduction degree higher than another two binders in this study. Total iron content in reduced iron is attained to $98.33 \%$ with $1 \%$ of MHA extracted from "Baganuur" lignite. Reduction degree can be expressed by loss of oxygen.
\end{abstract}

Keywords: magnetite, MHA binder, reduction, briquette.

DOI: $10.17073 / 0368-0797-2020-6-419-427$

\section{INTRODUCTION}

Steel is one of the most important much applied, and low cost metal materials in modern industry. At present the scale of the steel industry is constantly expending, iron and steel production technology is developing and improving. Direct reduction (DR) technological process is also developing toward compact, efficient, continuous, clean and environmentally friendly directions [1]. According to statistics of the International Iron and Steel Association, the production of crude steel in the world increased in 64 countries reporting 151.7 million tones (Mt) in August 2018, a $2.6 \%$ increase compared to August 2017 [2].

Direct reduced iron is main source of crude steel making, and its production also constantly increases due to the increase of steel production as shown in Fig. 1 [3]. Mongolia has rich resources of iron ore and coal which evenly distribute throughout the Mongolian territory. Measured geological reserves contain 1 billion tons of iron ore, 162.3 billion tons of coal, and these would obviously increase in the future. There is a lack of steel production from iron ore, especially for direct reduction plants for steel making in Mongolia. According to statistics of the Mineral Resource Agency of Mongolia, mining products account for $16 \%$ of gross domestic product (GDP), and $70 \%$ of total industrial product at last three years [4].

According to the statistic of Mongolian Customs Agency for last 10 years, 4 million tons of iron concentrate are exported and 140 thousand tons of steel armature for con- struction are annually imported from foreign various countries (Fig. 2) [5].

Binders are widely used in agglomeration operations, such as briquetting and making pellets, to assure the desired agglomeration properties with regard to subsequent handling, transportation and processing [6].

There are two major binder groups of organics and inorganics. Previously many studies have proved that effect of MHA binder on mechanical strength of pellets is greater than of bentonite. And consumption of MHA binder is low-

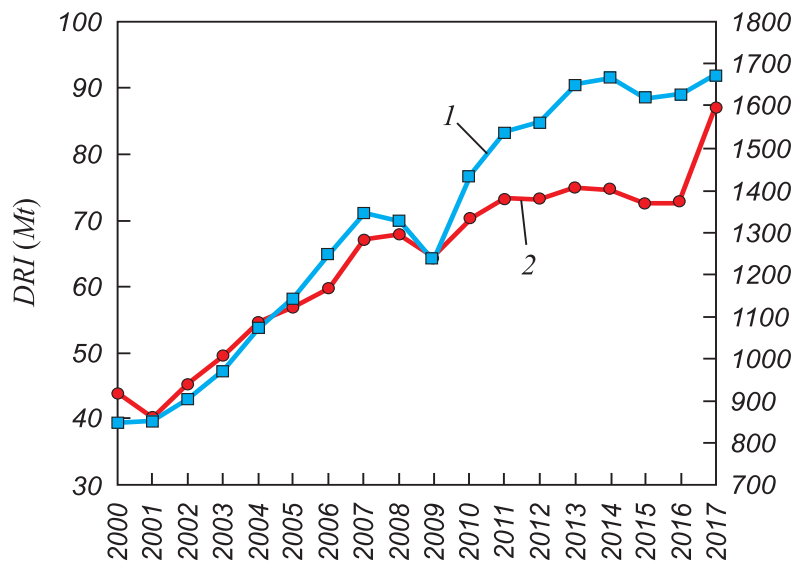

Year

Fig. 1. World crude steel (1) and DRI (2) production by years

Рис. 1. Мировое производство нерафинированной стали (1) и железа прямого восстановления (2) по годам 

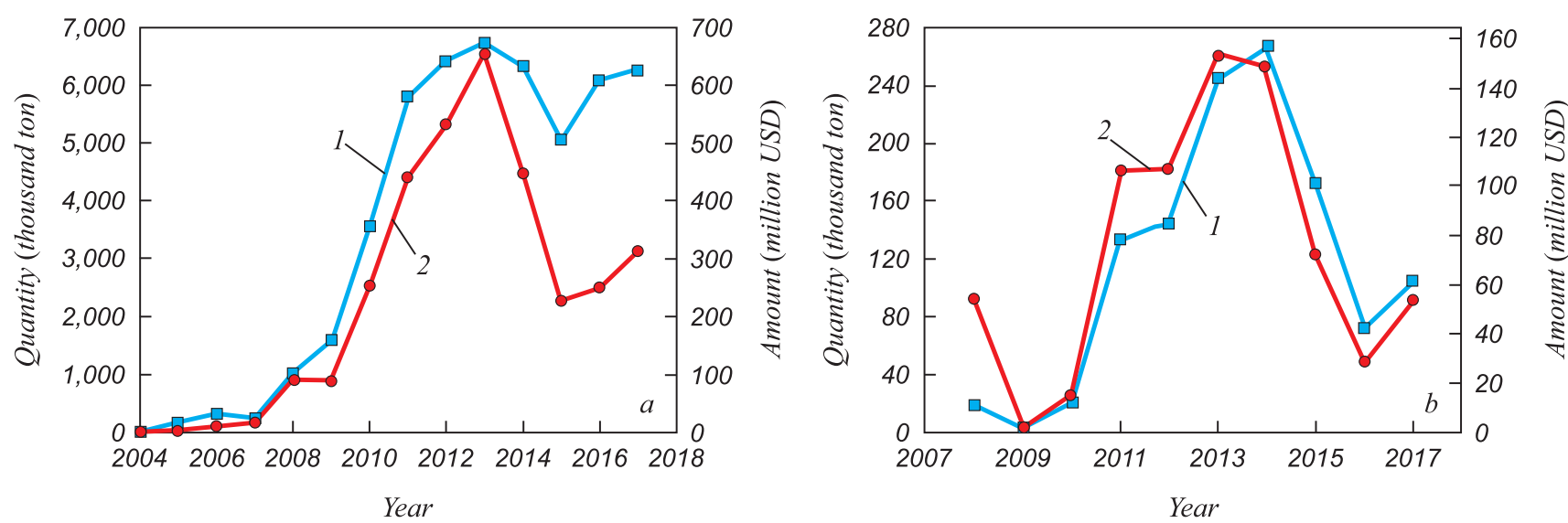

Fig. 2. Dynamic statistics of Mongolian customs:

$a$-exported iron ore; $b$-imported steel product (armature); 1 - quantity; 2 - amount

Рис. 2. Статистика монгольской таможни:

$a$ - экспортируемая железная руда; $b$ - импортируемый стальной продукт (арматура); 1 - количество; 2 - общая стоимость

er compared with bentonite [7 - 8]. Lignite and brown coal with great resources in Mongolia [9] could be used as the main source of humic substances for the preparation of organic binder. A type of novel organic binders namely modified humic acid (MHA) binder, with high binding property and economic benefits have been developed by Central South University (CSU) in China [10]. The MHA binder is comprised of organic (i.e. fulvic acid, humic acid) and inorganic active fractions [11].

Benefits to using organic binder: Organic binders might be used for a variety of reasons, but perhaps, the most reported benefit is a reduction in pellet silica content. The traditional binder, bentonite clay, generally increases silica content in iron ore pellet by $0.5 \%$ depending on bentonite dosage and composition. Organic binders are combusted during the roasting process, and may leave virtually no ash residue among the pellet microstructure of roasted pellet [12]. Ac- cording to many previous investigations, effect of the most organic binders leads to the required characteristics of roasted pellets [13].

\section{MATERIALS AND METHODS}

\section{Materials}

The magnetite concentrate is taken from "Tumurtei" mine in Mongolia. The iron concentrate sample went to size distribution test presented in Table 1. The iron concentrate particle size is too coarse, under below 200 mesh part is $28.13 \%$, thus it needs to be ground. Then chemical composition of the ground sample was tested by XRF (Table 2). The concentrate sample contained, (\% mass.): $65.85 T_{\mathrm{Fe}}$, $1.70 \mathrm{Al}_{2} \mathrm{O}_{3}, 3.44 \mathrm{SiO}_{2}$ and $1.55 \mathrm{MgO}$. Particle size distribution and specific surface area of the sample were sepa-

Table 1

Size distribution of the sample

Таблица 1. Гранулометрический состав образца

\begin{tabular}{c|c|c|c|c|c}
\hline Size, $\mathrm{mm}$ & +0.100 & $-0.1 \ldots+0.074$ & $-0.074 \ldots+0.045$ & $-0.045 \ldots+0.032$ & -0.032 \\
\hline Content, $\%$ & 62.56 & 9.31 & 15.67 & 4.52 & 7.95 \\
\hline
\end{tabular}

Chemical composition of the iron ore concentrate

Таблица 2. Химический состав железорудного концентрата

\begin{tabular}{c|c|c|c|c|c|c|c|c|c}
\hline Components & $T_{\mathrm{Fe}}$ & $\mathrm{FeO}$ & $\mathrm{Fe}_{2} \mathrm{O}_{3}$ & $\mathrm{CaO}$ & $\mathrm{MgO}$ & $\mathrm{Al}_{2} \mathrm{O}_{3}$ & $\mathrm{SiO}_{2}$ & $\mathrm{TiO}_{2}$ & $\mathrm{Mn}$ \\
\hline Content, $\%$ & 65.85 & 24.08 & 94.15 & 0.48 & 1.56 & 1.70 & 3.44 & 0.49 & 0.069 \\
\hline Components & $\mathrm{P}$ & $\mathrm{S}$ & $\mathrm{Cu}$ & $\mathrm{K}_{2} \mathrm{O}$ & $\mathrm{Na}_{2} \mathrm{O}$ & - & - & - & - \\
\hline Content, ppm & 18.69 & 330.04 & 7.57 & $1,529.97$ & 137.68 & - & - & - & - \\
\hline
\end{tabular}


rately tested by water sieving method and air permeability method (DBT-127 model), the content of the sample below $0.074 \mathrm{~mm}$ after grinding was higher than $80 \%$. The specific surface area of the sample was $649.53 \mathrm{~cm}^{2} / \mathrm{g}$. Texture of the iron ore concentrates which was measured by Leica optical microscope and XRD pattern, is shown on Fig. 3, indicating the main minerals: magnetite, hematite and quartz associated with each other closely.

The main mineral composition of "Tumurtei" iron ore concentrate was identified as principally magnetite $\left(\mathrm{Fe}_{3} \mathrm{O}_{4}\right)$ and hematite $\left(\mathrm{Fe}_{2} \mathrm{O}_{3}\right)$ as shown on Fig. 4.

In this study, 3 different lignites namely $A, B$ and $C-$ "Baganuu", "Khuut" and "Liling" were used. Mongolian coal $A$ and $B$, and coal $C$ from Liling in Hunan Province, China were selected. As well-known, lignite contains organic and inorganic constituents simultaneously [14].

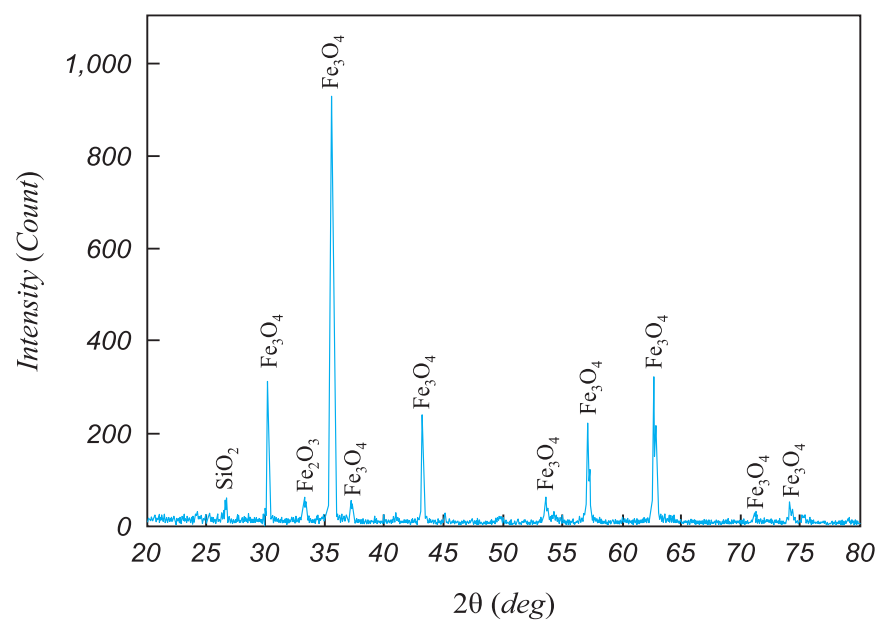

Fig. 3. XRD pattern of magnetite concentrate

Рис. 3. Рентгенограмма магнетитового концентрата

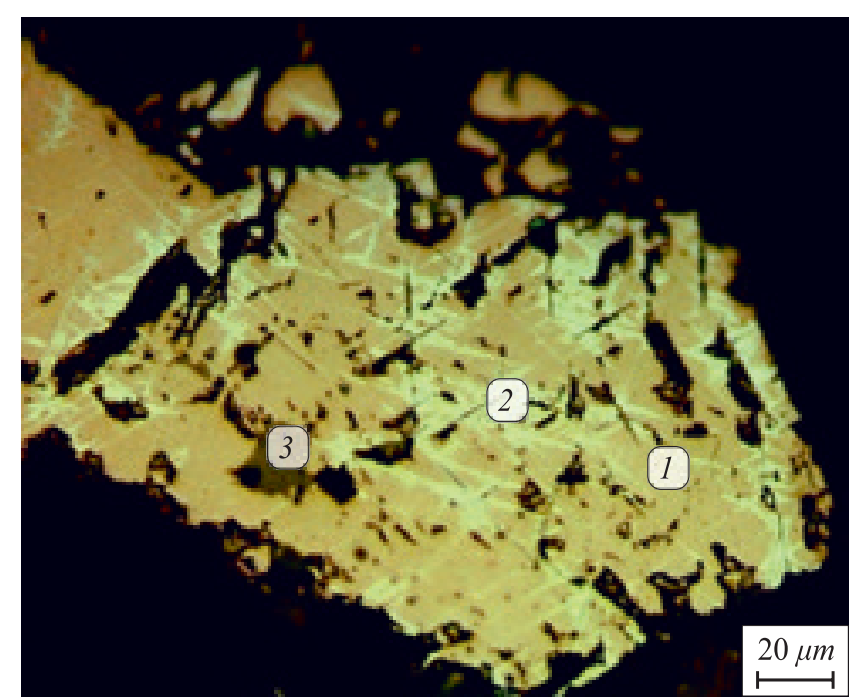

Fig. 4. Single particle microstructure of iron ore concentrate: 1 - magnetite; 2 - hematite; 3 - quartz

Рис. 4. Микроструктура частицы железорудного концентрата: 1 - магнетит; 2 - гематит; 2 - кварц
Table 3

Proximate analysis of lignite coal (\% mass.)

Таблица 3. Примерный анализ бурого угля, \% (по массе)

\begin{tabular}{c|c|c|c|c|c|c}
\hline \multirow{2}{*}{ Coal } & \multicolumn{7}{|c}{ Proximate analysis } \\
\cline { 2 - 7 } & $W, \%$ & $V, \%$ & Ash, \% & $\mathrm{FC}$ & $Q, \mathrm{kCal} / \mathrm{kg}$ & $\mathrm{TC}$ \\
\hline$A$ & 9.00 & 39.44 & 10.50 & 41.06 & 6,004 & 70.5 \\
\hline$B$ & 5.39 & 48.04 & 3.50 & 43.03 & 5,775 & 73.1 \\
\hline$C$ & 3.20 & 34.79 & 22.58 & 39.43 & 5,236 & - \\
\hline
\end{tabular}

At the beginning, the samples were homogenized and dried, then crushed to powders with the granularity below $0.074 \mathrm{~mm}$ [15]. The proximate analysis of lignite indicates that these samples consists of $39.44 \%$. The proximate analysis of lignite indicates that these samples consists of $39.44,48.04$ and $34.79 \%$ of volatile matter, the ash contents were $10.50,3.50,22.58 \%$, the grade of fixed carbon $41.00,43.00,39.43$ in coal $A, B$ and $C$, respectively, measured by Sundy SDTGA5000 analyzer (Table 3).

\section{Methods}

\section{Extraction of MHA from lignite.}

MHA was extracted from three different lignites (noted above) under same conditions. Powdered and homogenized brown coal was mixed with distilled water chemical pure $0.5 \mathrm{M}$ of sodium-hydroxide in a glass flask. Substances ratio and stirring speed, $\mathrm{pH}$ values are obtained from the studies [16]. MHA solution and sediments were subjected to drying until full drying at $60{ }^{\circ} \mathrm{C}$ in a drying furnace; then the weight was determined. Finally extraction yield of MHA was calculated according to the balance of products. The extraction flow sheet is shown in Fig. 5.

The chemical composition of varies MHA binder were determined by XRF as presented below:

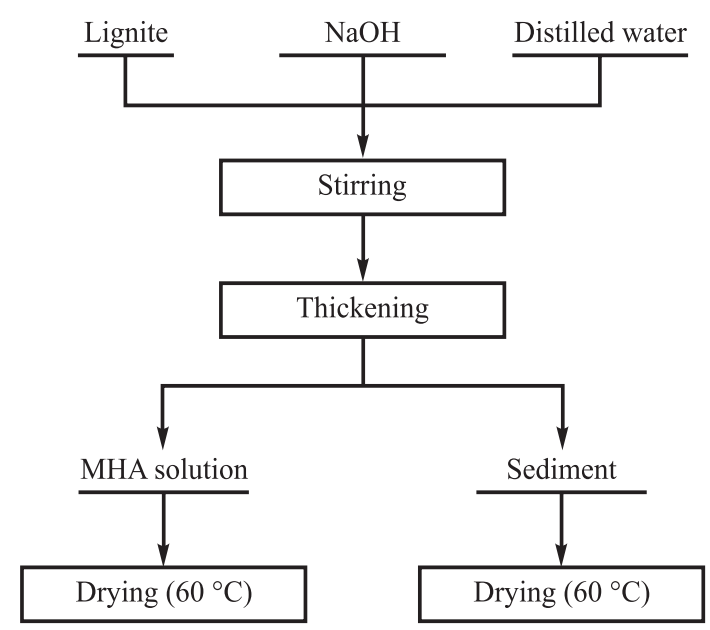

Fig. 5. Extraction flow of MHA binder from lignite

Рис. 5. Схема извлечение связующего МНА из бурого угля 


$\begin{array}{cccc}\text { Coal } & A & B & C \\ \mathrm{Fe}_{2} \mathrm{O}_{3} & 5.43 & 4.92 & 12.80 \\ \mathrm{~K}_{2} \mathrm{O} & 0.82 & 0.55 & 1.16 \\ \mathrm{Na}_{2} \mathrm{O} & 48.95 & 53.05 & 8.04 \\ \mathrm{SiO}_{2} & 21.17 & 13.11 & 43.41 \\ \mathrm{Al}_{2} \mathrm{O}_{3} & 9.42 & 5.66 & 25.22 \\ \mathrm{CaO} & 2.24 & 7.54 & 1.05 \\ \mathrm{MgO} & 0.76 & 1.57 & 0.69 \\ \mathrm{P}_{2} \mathrm{O}_{5} & 0.19 & 0.17 & 0.20 \\ \mathrm{SO}_{3} & 8.53 & 10.58 & - \\ \mathrm{TiO}_{2} & 0.11 & 0.26 & - \\ & & & \end{array}$

\section{Preparation of binder briquettes.}

Preparation of the samples for briquetting process was carried out by mixing a certain amount of magnetite concentrate with different stoichiometric amount of MHA binder ranging from 0.5 up to 1.5 stoichiometric ratios. Those amounts of binders were extracted from selected lignites under alkaline condition.

The mixture of raw materials and $8 \%$ water were input in a mold; then placed in small scale hydraulic presser described on Fig. 6 . Green briquette with a diameter $10 \mathrm{~mm}$
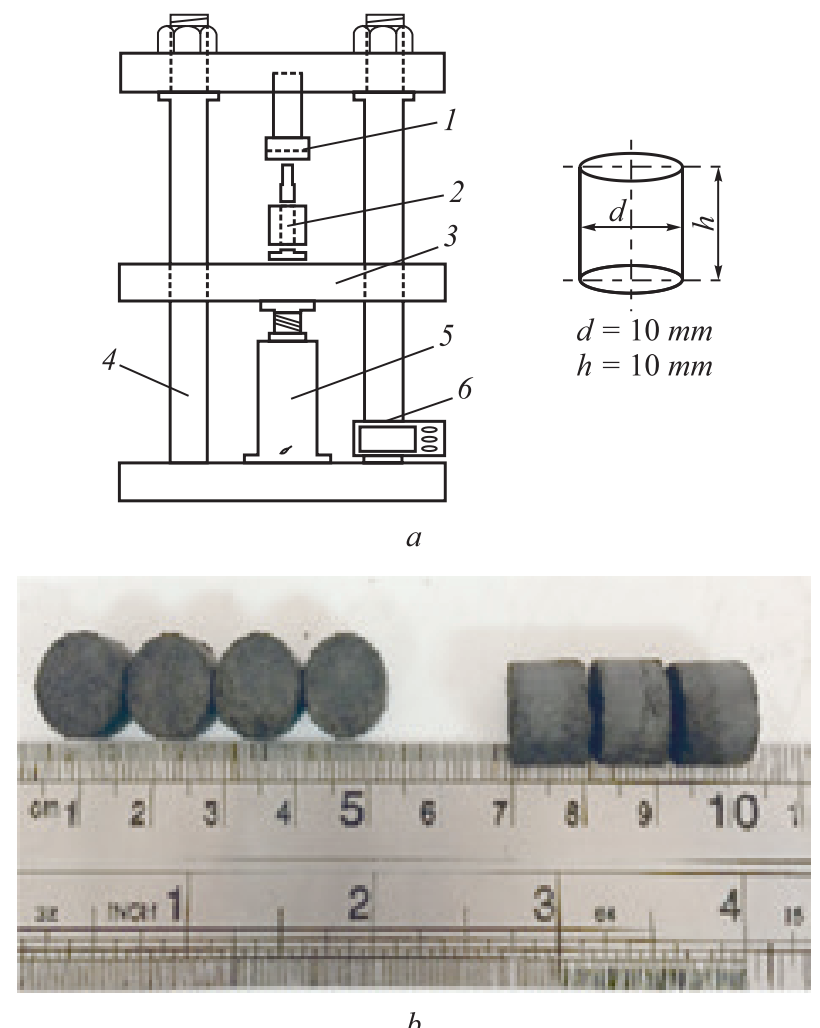

Fig. 6. Schematic layout of hydropresser $(a)$ and appearance of green briquette $(b)$ :

1 - sensor pressure; 2 - metal cylinder bottle; 3 - movable plate; 4 - vertical core; 5 - hydraulic pressire; 6 - pressing strength controller

Рис. 6. Схема гидропресса $(a)$ и внешний вид зеленого брикета $(b)$ : 1 - sensor pressure; 2 - metal cylinder bottle; 3 - movable plate; 4 - vertical core; 5 - hydraulic pressire; 6 - pressing strength controller and a height $\approx 10 \mathrm{~mm}$ was produced under different conditions such as pressure and pressing time to making observed optimal condition. The green briquettes were dried at $100{ }^{\circ} \mathrm{C}$ to obtain dry briquette. Then the produced briquettes were subjected to mechanical tests including dropping damage resistance test and compressive strength test.

\section{Mechanical strength tests.}

Ten green briquettes are individually dropped from a height of $50 \mathrm{~cm}$ onto a steel plate until breakage. The mean value of the tested briquettes gives their average dropping damage resistance [17].

The compassion strength of green briquettes was determined, at least 10 briquettes sample were compressed on small size hydraulic press until they break onto electric balance. The compression strength of roasted-oxidized ten briquettes was determined by a universal material experimental machine (RHY-100B, China). The mean value for the tested briquettes gives their compressive strength. The observed load corresponds to the compressive strength measured in MPa for briquette [18].

\section{Reduction, roasting tests and phase characteristic analysis.}

The preheating and roasting tests were observed in a laboratory scale of horizontal electrically heated tube furnace with an internal diameter of $50 \mathrm{~mm}$ and an external diameter of $70 \mathrm{~mm}$, schematically described on Fig. 7. Ten dry briquettes which contain $0.5-1.5$ stoichiometric amount of three different MHA were placed in corundum crucible, and then pushed into the preheating zone of the furnace. The preheated sample was slowly and carefully

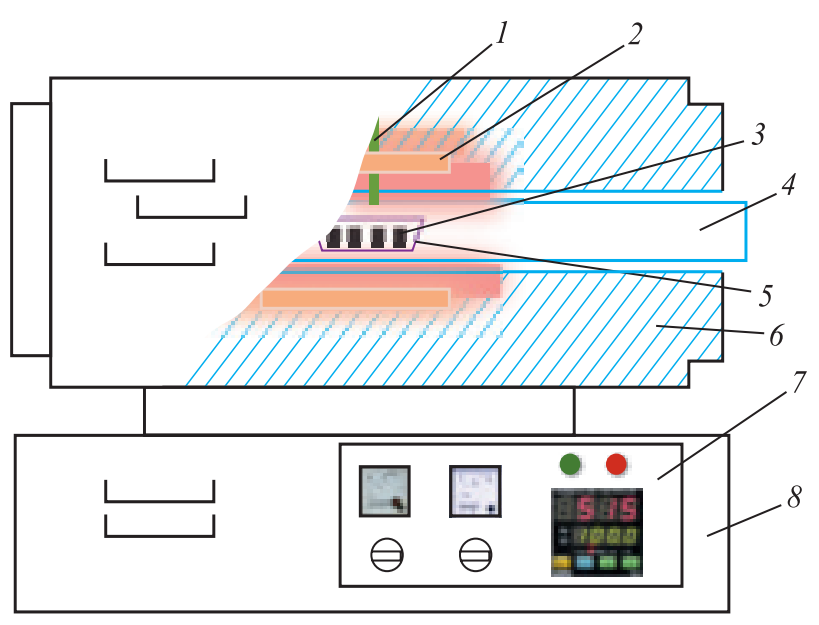

Fig. 7. Schematic layout of laboratory electric furnace: 1 - thermocouple; 2 - heating resistor; 3 - sample; 4 - corundum tube; 5 - corundum substrate; 6 - refractory lining; 7 - control panel and electrical switch; 8 - main core

Рис. 7. Схема лабораторной электропечи:

1 - термопара; 2 - нагревательный резистор; 3 - образец; 4 - корундовая трубка; 5 - корундовая подложка; 6 - огнеупорная футеровка; 7 - панель управления и электрический выключатель; 8 - основной корпус 
pushed to appointed temperature of roasting zone. Finally, the roasted samples were pulled out and naturally cooled in room temperature [18]. Heating was carried out at different temperatures ranging from $950{ }^{\circ} \mathrm{C}$ up to $1150{ }^{\circ} \mathrm{C}$ for a different time. To heated at different temperatures, temperature ranging from $950{ }^{\circ} \mathrm{C}$ up to $1150{ }^{\circ} \mathrm{C}$ for a different time. The gas consumption of $\mathrm{CO}$ as reducer was constant $(4 \mathrm{~L} / \mathrm{min})$ at the reduction tests.

\section{Optical microscope observation.}

The microstructures of polished briquettes before and after reduction were studied using a Leica DMRXE microscope (Germany).

\section{RESULTS END DISCUSSION}

\section{Effect of binder dosage on properties \\ of green briquette}

The drop damage resistance and compressive strength of the green briquettes are shown in Fig. (4b), with respect to the different stoichiometric amounts of MHA binder under optimized briquetting load of 0.75 ton for fine magnetite ( $+80 \%$ of $-0.074 \mathrm{~mm}$ fraction) concentrate. It was found that the drop damage resistance and compressive strength of produced briquettes increased with increasing binder dosage for every constant load and reached its maximum value at 1.5 stoichiometric amounts of binder fines for both concentrate sizes. The compressive strength of "Bg" green briquettes from fine concentrate with $\mathrm{Bg}$ MHA reached 12.32 MPa which is higher than for "Li" MHA of briquetts. The results of mechanical strengths tests of green briquettes are presented in Table 4 and Fig. 8.

Parameters of briquetting process were carried out according to the no-binder briquetting test $0.75 \mathrm{t} \cdot \mathrm{cm}^{-2}$ pressure, 5 seconds pressing time, $8 \%$ of moisture content.

\section{Effect of binder dosage on properties of roasted briquette}

Firstly the roasting of produced briquettes at different temperatures ranging from $850{ }^{\circ} \mathrm{C}$ up to $1100{ }^{\circ} \mathrm{C}$ for different time at ambient atmosphere leads to optimized time and temperature. Optimal conditions of roasting-oxidation were $10 \mathrm{~min}$ and $950^{\circ} \mathrm{C}$. The temperature range is $10^{\circ} \mathrm{C}$ per minute noted other before investigation. CCS of "Kh" is higher than "Bg" and "Li" briquettes, but $\mathrm{FeO}$ content of "Kh" increased with increasing MHA dosage (Fig. 9). Organic birders are easily burned out during roasting, leading to the generation of porosity as shown in Fig. 10. The poro-

\section{Effect of various MHA dosage on mechanical strength}

Таблицุа 4. Влияние количества МНА на механическую прочность

\begin{tabular}{c|c|c|c|c|c|c|c|c|c|c}
\hline Green briquette & \multicolumn{4}{|c|}{ Compressive strength, MPa } & \multicolumn{5}{c}{ Dropping number, N } \\
\hline MHA dosage & 0.50 & 0.75 & 1.00 & 1.25 & 1.50 & 0.50 & 0.75 & 1.00 & 1.25 & 1.50 \\
\hline $\mathrm{Bg}(\operatorname{coal} A)$ & 3.50 & 3.60 & 4.70 & 4.99 & 5.40 & 1.30 & 1.50 & 2.20 & 2.50 & 2.80 \\
\hline $\mathrm{Kh}(\operatorname{coal} B)$ & 6.40 & 8.20 & 10.3 & 12.32 & 12.43 & 1.70 & 2.30 & 2.50 & 4.30 & 4.30 \\
\hline $\mathrm{Li}(\operatorname{coal} C)$ & 7.67 & 8.33 & 9.57 & 9.43 & 9.23 & 1.90 & 2.00 & 2.60 & 2.70 & 3.20 \\
\hline
\end{tabular}
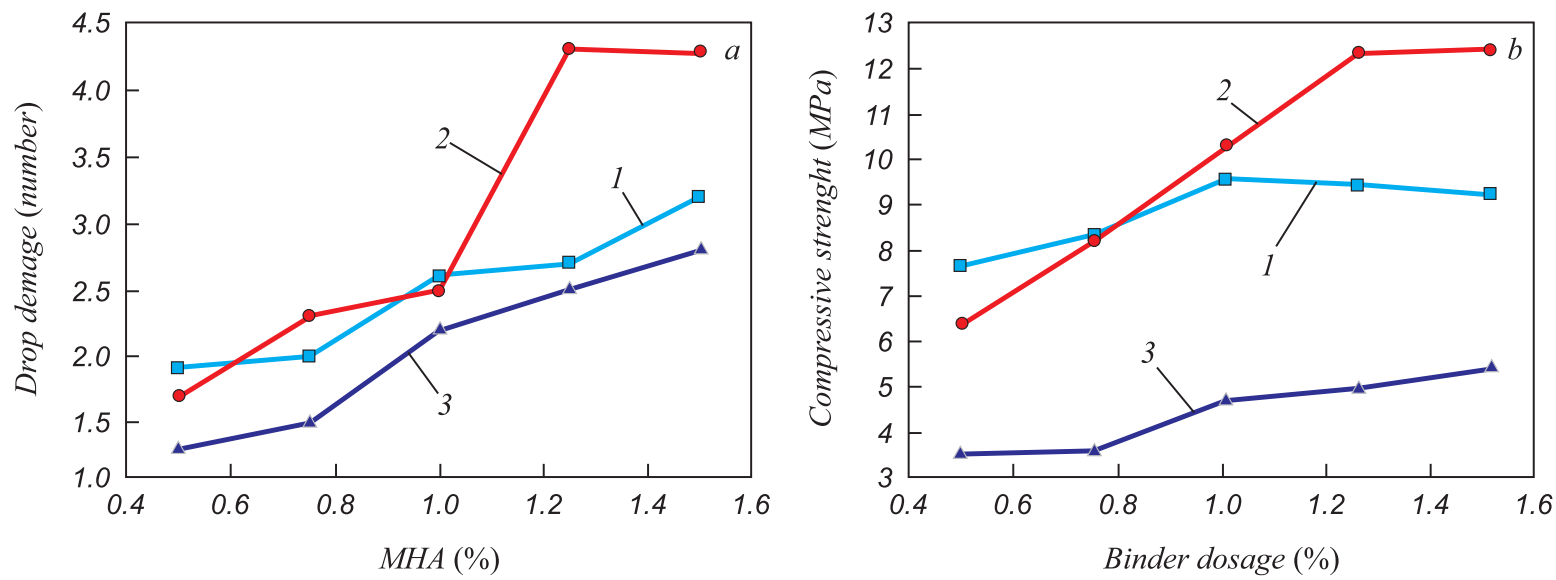

Fig. 8. Effect of MHA dosage on drop damage $(a)$ and compressive strength $(b)$ of green briquettes: $1-\mathrm{Li} ; 2-\mathrm{Kh} ; 3-\mathrm{Bg}$

Рис. 8. Влияние количества МНА на устойчивость при падении (a) и прочность на сжатие $(b)$ зеленого брикета: $1-\mathrm{Li} ; 2-\mathrm{Kh} ; 3-\mathrm{Bg}$ 


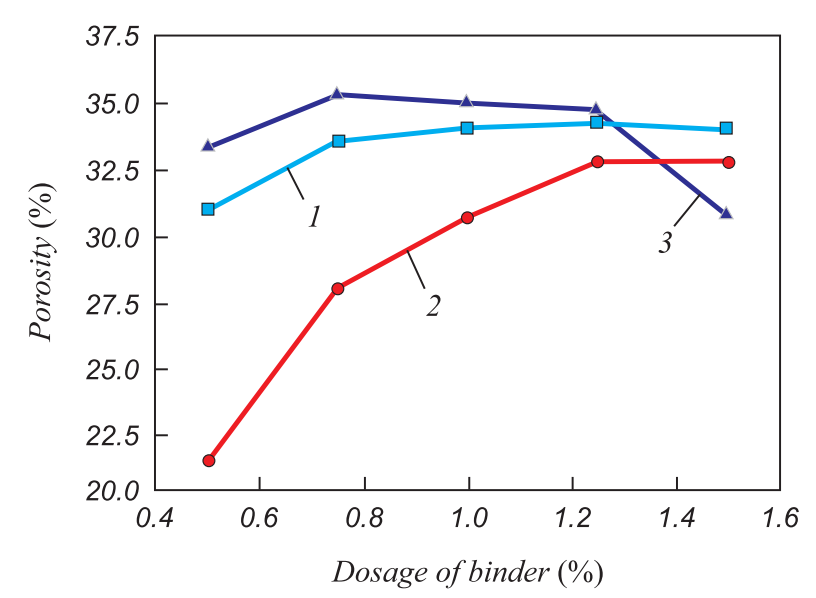

Fig. 9. Effect of MHA dosage on the porosity of roasted briquettes: $1-\mathrm{Li} ; 2-\mathrm{Kh} ; 3-\mathrm{Bg}$

Рис. 9. Влияние количества МНА на пористость обожженных брикетов:

$$
1-\mathrm{Li} ; 2-\mathrm{Kh} ; 3-\mathrm{Bg}
$$

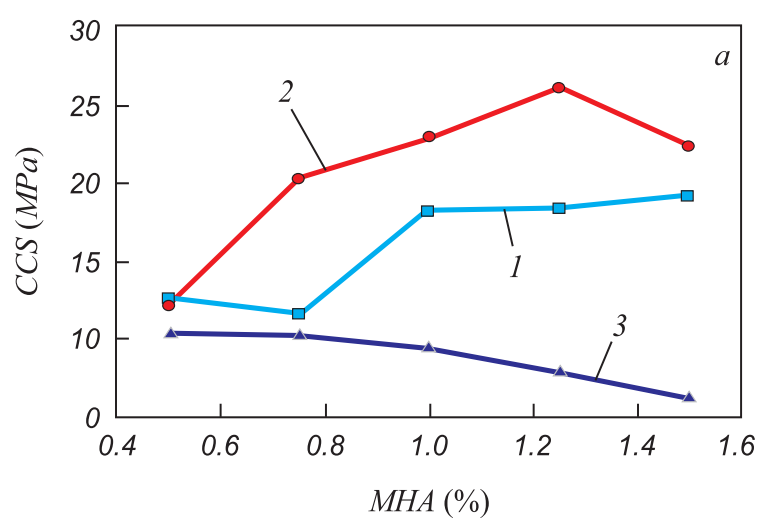

sity [19] is the most important factor to extent of reduction (Fig. 6, 8).

\section{Effect of various MHA on reduced magnetite briquettes}

The reduction procedure of magnetite briquettes with MHA binders extracted from different lignites was made in laboratory type electrical furnace in the $\mathrm{CO}$ atmosphere (Fig. 3).

The reaction of $\mathrm{Fe}_{3} \mathrm{O}_{4}$ to $\mathrm{Fe}$ by $\mathrm{CO}$ is:

$$
\begin{gathered}
3 \mathrm{Fe}_{2} \mathrm{O}_{3}+\mathrm{CO}=2 \mathrm{Fe}_{3} \mathrm{O}_{4}+\mathrm{CO}_{2} \\
\mathrm{Fe}_{3} \mathrm{O}_{4}+\mathrm{CO}=3 \mathrm{FeO}+\mathrm{CO}_{2} \\
\mathrm{FeO}+\mathrm{CO}=\mathrm{Fe}+\mathrm{CO}_{2} .
\end{gathered}
$$

The results are presented on the Fig. 3 in terms of the percent reducing extent against temperature due to oxygen

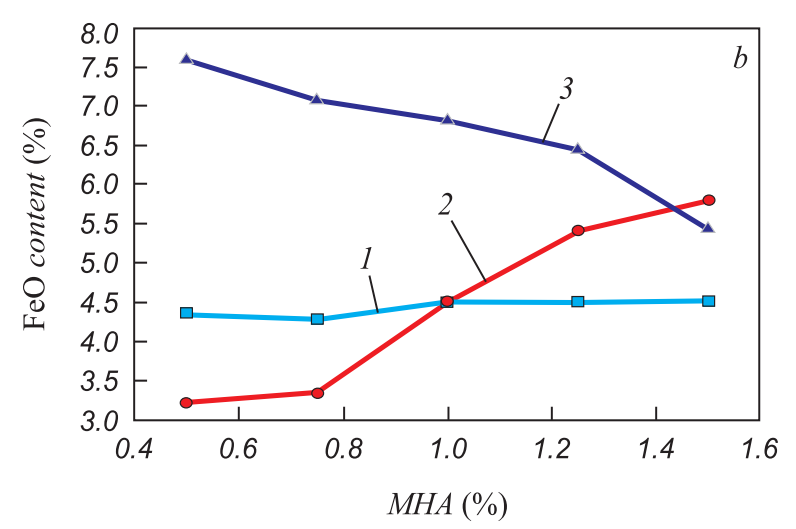

Fig. 10. Effect of MHA binder dosage on compressive crushing strength $(a)$ and $\mathrm{FeO}$ content $(b)$ at $950{ }^{\circ} \mathrm{C}$ for 10 min: $1-\mathrm{Li} ; 2-\mathrm{Kh} ; 3-\mathrm{Bg}$

Рис. 10. Влияние количества связующего МНА на прочность при сжатии $(a)$ и содержание $\mathrm{FeO}(b)$ при $950{ }^{\circ} \mathrm{C}$ в течение 10 мин: $1-\mathrm{Li} ; 2-\mathrm{Kh} ; 3-\mathrm{Bg}$
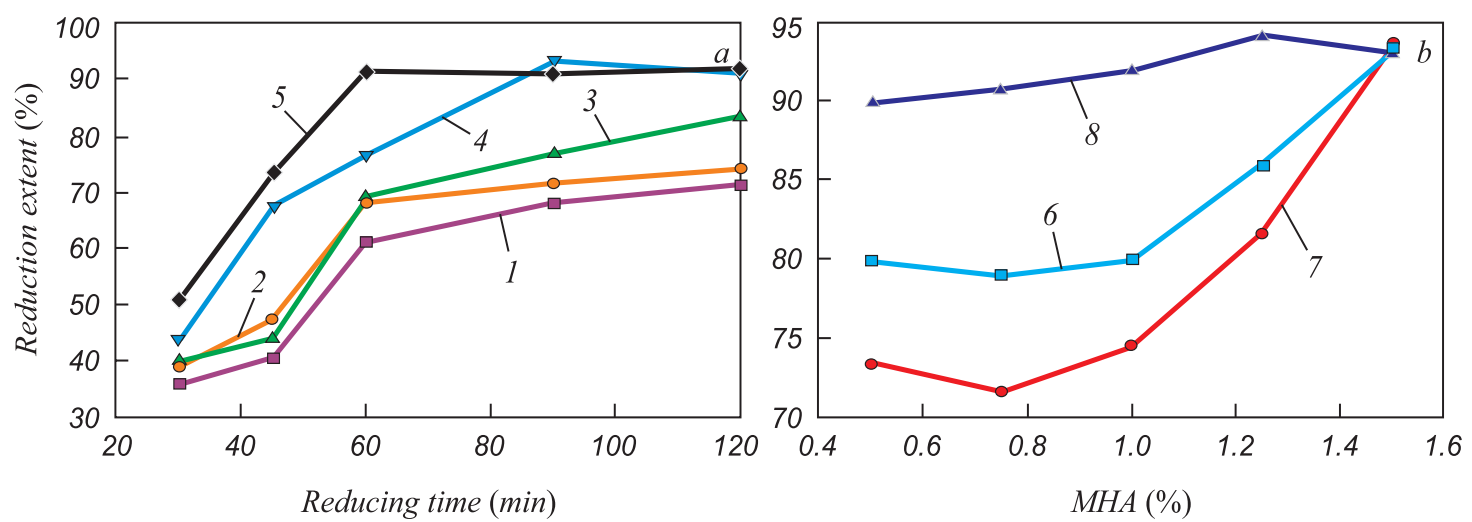

Fig. 11. Relation between reduction extent and reduction time under different temperature at ${ }^{\circ} \mathrm{C}$ : 950 (1); 1000 (2); $1050(3) ; 1100(4) ; 1150(5)$ ) without binder $(a)$; relation between reduction extent and different stoichiometric amount of various MHA: $\mathrm{Li}(6) ; \mathrm{Kh}(7) ; \mathrm{Bg}(8)$ at $1100{ }^{\circ} \mathrm{C}, 90 \mathrm{~min}(b)$

Рис. 11. Соотношение между степенью восстановления и временем восстановления при разных температурах, ${ }^{\circ} \mathrm{C}: 950$ (1); 1000 (2); 1050 (3); 1100 (4); 1150 (5) (a); соотношение между степенью восстановления и стехиометрическим количеством различных МНА: $\mathrm{Li}\left(\right.$ (); $\mathrm{Kh}(7) ; \operatorname{Bg}(8)$ при $1100{ }^{\circ} \mathrm{C}, 90$ мин (b) 
loss by $\mathrm{CO}$ gas which was produced during the reduction. The reduction degree was calculated by mass loss and $\mathrm{FeO}$ content was defined as:

$$
R_{t}=100\left(\frac{0.11 W_{1}}{0.43 W_{2}}+\frac{m_{1}-m_{2}}{m_{2} 0.43 W_{2}} 100\right),
$$

$R_{t}$ - reduction degree, $\% ; W_{1}-\mathrm{FeO}$ content of oxidized briquettes before reduction, $\% ; W_{2}$ - total iron content before reduction, $\% ; m_{1}$ - mass of sample before reduction, g; $m_{2}-$ mass of reduced briquettes, $\mathrm{g}$.

The phase characteristics of the magnetite concentrate before and after reduction at these temperatures were analyzed by XRD [RIGAKU D/Max 2500, Japan] under the conditions of radiation: $\mathrm{Cu} K \alpha$ tube, current and voltage: $250 \mathrm{~mA}, 40 \mathrm{kV}$, scanning range: $10-80^{\circ}(2 \theta)$, step size $0.02^{\circ}(2 \theta)$ and scanning speed $8^{\circ} / \mathrm{min}$ (Fig. 12).

\section{CONCLUSIONS}

The influence of modified humic acid on the carbothermal reduction of a magnetite concentrate by temperature programmed reduction ranging from $950{ }^{\circ} \mathrm{C}$ to $1150{ }^{\circ} \mathrm{C}$ for different reducing time is shown on microstructure of the samples on the Fig. 13 and can be summarized as follows.

The mechanical strength of oxidized pellet with "Bg" binder extracted from coal A decreased but extent of reduction was stable and higher than with "Kh", "Li" with increasing binder dosage. The highest reduction ratio is $94.12 \%$ with $1.25 \%$ stoichiometry amount of "Bg" MHA. Relation between both "Kh", "Li" binder dosage and reduction extent is immediately increasing under the same indicated condition: $1100{ }^{\circ} \mathrm{C}$ for $90 \mathrm{~min}$.

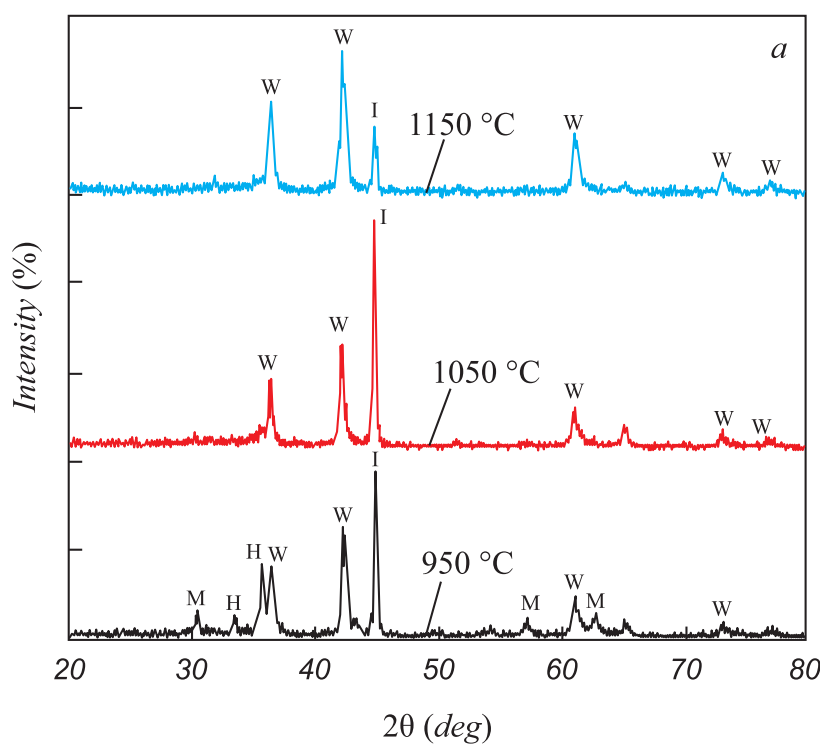

\section{REFERENCES}

1. Jiang T., Qiu G., Xu J., Zhu D., Singh R. Direct Reduction of Composite Binder Pellets and Use of DRI. Electrotherm Press, Ahmedabad, India, 2007, pp. 35-215.

2. World Steel Association, Statistics of international steel production 2018. Available at: https://www.worldsteel.org/en/dam/ jcr:5a5aa269-d357-476f-bbc3-74c0eacd5566/World\%2520Steel\%2 520in\%2520Figures\%25202018.pdf.

3. World direct reduction statistics. Englewood Cliffs, New Jersey, U.S.A. May, 2018. Available at: https://www.midrex.com/wp-content/uploads/Midrex_STATSbookprint_2018Final-1.pdf.

4. Statistic of mineral production 2018. Mineral Resource Agency of Mongolia. Ulan-Bator, Mongolia. Available at: https://www.mrpam. gov.mn/public/pages/131/monthly.report.2018.12.mon.pdf.

5. Foreign trade statistics of Mongolian Customs Agency 2004-2018. Available at: http://www.customs.gov.mn/statistics/index. php? module $=$ users $\&$ cmd $=$ info_full $\&$ cid $=1159 \&$ tid $=131$.

6. Sastry K.V.S., Fuerstenau D.W. Role of binders during pelletization of iron ore concentrate-pellet growth and strength aspects. In: Proc. of $4^{\text {th }}$ Int. Symposium on Agglomeration, Toronto, 1985, pp. 41-48.

7. Zhang Yuan-bo, Li Peng, Zhou You-lian, Han Gui-hong, Li Guanghui, Xu Bin, Jiang Tao. Adsorption of lignite humic acid onto magnetite particle surface. Journal of Central South University. 2012, vol. 19, pp. 1967-1972.

8. Zhang Yuan-bo, Han Gui-hong, Jiang Tao, Huang Yan-fang, Li Guang-hui, Guo Yu-feng, Yang Yong-bin. Structure characteristics and adhesive property of humic substances extracted with different methods. Journal of Central South University, 2011, vol. 18, pp. 1041-1046.

9. Jiang Tao, Li Guanghui, Zhang Yuanbo, Yang Yongbin, Han Guihong, Huang Yanfang, Guo Yufeng, Fan Xiaohui, Li Qian, Tang Zhaokun, Chen Xuling, Qiu Guanzhou. A kind of complex polymerbased pellet binder and its use method. Patient number: $\mathrm{CN}$ 101693950 A[P]. 2010-04-14.

10. Tao Jiang, Guihong Han, Yuanbo Zhang, Guanghui Li, Yangang Huang. A further study on the interaction between one of organic active fractions of the MHA binder and iron ore surface. Int. Journal of Mineral Processing. 2011, vol. 100, no. 3-4, pp. 172-178.

11. Guihong Han, Tao Jiang, Guanghui Li, Yanfang Huang, Yuanbo Zhang. Investigation on modified humic substances based binders

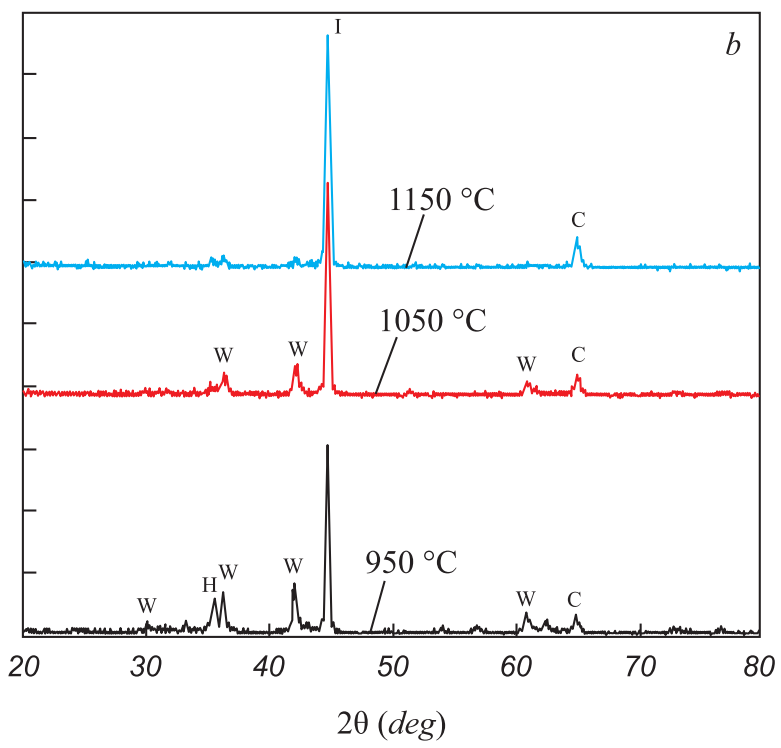

Fig. 12. XRD patterns of reduced briquettes under different temperature for $30 \mathrm{~min}(a)$ and $90 \mathrm{~min}(b): M$ - magnetite; $H$ - hematite; $I$ - metallic iron; $C$ - carbon

Рис. 12. Рентгенограммы восстановленных брикетов при различной температуре в течение 30 мин $(a)$ и 90 мин $(b): M$ - магнетит; $H$ - гематит; $I$ - металлическое железо; $C$ - углерод 

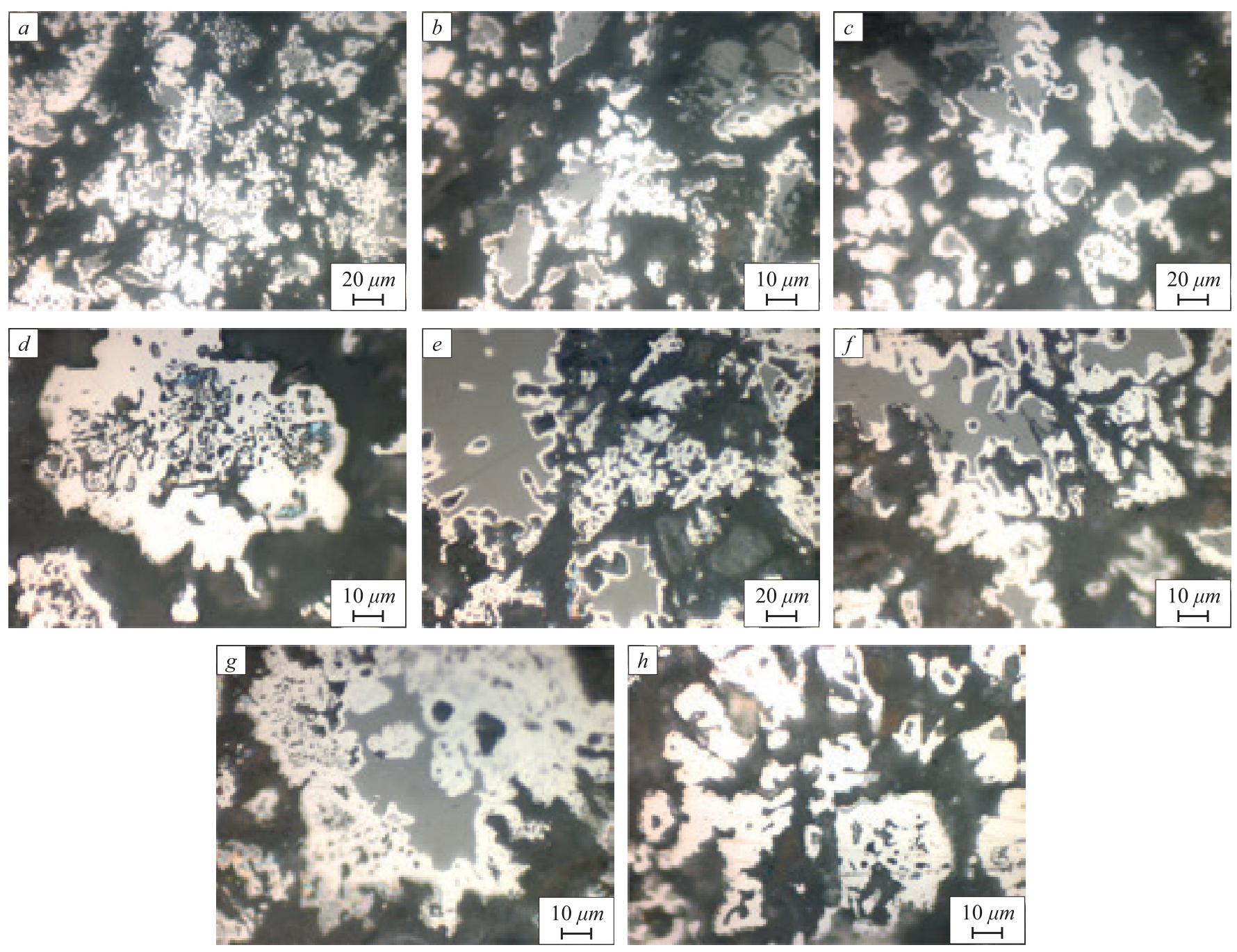

Fig. 13. Optical micrograph of reduced briquettes:

$a, b, c, d$ for $30,45,60,90 \mathrm{~min}$ at $1100^{\circ} \mathrm{C}, e, f, g, h$ for $90 \mathrm{~min}$ at $1000,1050,1100,1050{ }^{\circ} \mathrm{C}$, respectively; white zone - iron; grey zone - wustite; dark zone - porosity and hole

Рис. 13. Микроструктура восстановленных брикетов:

$a, b, c, d$ в течение $30,45,60,90$ мин при $1100{ }^{\circ} \mathrm{C}$ соответственно; $e, f, g, h$ в течение 90 мин при $1000,1050,1100,1050{ }^{\circ} \mathrm{C}$ соответственно; белая зона - железо; серая зона - вюстит; темная зона - пористость и пустоты

for iron ore agglomeration. Journal of Engineering Materials and Technology-Transactions of the ASME. 2012, vol. 134, no. 1, article 010901-5.

12. Haas L.A, Aldinger J.A, Nigro J.C. Effectiveness of organic binders for iron ore pelletization. Report of Investigations. U.S. Bureau of Mines, RI 9230, 1989, 25 p.

13. Srivastava Ur., Kawatra S.K., Eisele T.C. Study of organic and inorganic binders on strength of iron oxide pellets. Metallurgical and Materials Transactions B - Process Metallurgy and Materials Processing Science. 2013, vol. 44, no. 4, pp. 1000-1009.

14. Tao Jinag, Guihong Han, Yuanbo Zhang, Yanfang Huang, Guanghui Li, Yufeng Guo, Youngbin Ynag. Improving extraction yield of humic substances from lignite with anthraquinone in alkaline solution. Journal of Central South University. 2011, vol. 18, pp. 68-72.

15. James G. Speight. Handbook of coal analysis. USA, 240 p.

16. Forsmo S.P.E., Samskog P.O., Björkman B.M.T. A study on plasticity and compression strength in wet iron ore green pellets related to real process variations in raw material fineness. Powder Technology. 2008, vol. 181, no. 3, pp. 321-330.

17. Forsmo S.P.E., Apelqvist A.J., Björkman B.M.T., Samskog P.O. Binding mechanisms in wet iron ore green pellets with a bentonite binder. Powder Technology. 2006, vol. 169, no. 3, pp. 147-158.

18. Jiang Tao, Zhang Yuan-bo, Huang Zhu-cheng, Li Guang-hui, Fan Xiao-hui. Preheating and roasting characteristics of hematite-magnetite (H-M) concentrate pellets. Ironmaking \& Steelmaking. 2008, vol. 35, no. 1, pp. 21-26.

19. Peter Klobes, Klaus Meyer, Ronald G. Munro. Porosity and Specific Surface Area Measurements for Solid Materials. Special Publications 960-17, September 2006. Available at: https://nvlpubs.nist. gov/nistpubs/Legacy/SP/nistspecialpublication960-17.pdf

Received April 9, 2019

Revised June 15, 2020 Accepted June 16, 2020 


\section{ВЛИЯНИЕ МОДИФИЦИРОВАННОЙ ГУМИНОВОЙ КИСЛОТЫ (МНА) КАК СВЯЗУЮЩЕЙ ДОБАВКИ НА ОБЖИГ БРИКЕТИРОВАННОГО МОНГОЛЬСКОГО ЖЕЛЕЗОРУДНОГО КОНЦЕНТРАТА «TUMURТЕI»}

\section{Баяра Сараатанбазар, Гуан-хуэй Ли}

Школа обогащения полезных ископаемых и биоинженерии, Центральный Южный университет (410083, Китай, Чанша, Хунань)

Аннотация. Существуют две основные группы связующих добавок: органические и неорганические для агломерационного процесса и спекающие для производства стали. В данной работе изучено влияние композиционного связующего на обжиг монгольских брикетов из железорудного концентрата «Tumurtei» в атмосфере воздуха с целью выявления оптимальных параметров их поведения при обжиге с тремя различными связующими МНА для прямого восстановления. Лигнит содержит органические и неорганические вещества и, согласно многим предшествующим исследованиям, он может быть сырьем для извлечения композиционного связующего. Прессованный железный концентрат со связующим МНА подвергали процессу окисления и восстановления в электропечи. Оптимальные условия экспериментов были следующими. Параметры процесса брикетирования выполнены в соответствии с испытанием на сжатие без связующего при давлении $0,75 \mathrm{~T} \cdot \mathrm{cm}^{-2}$, времени прессования 5 с, содержании влаги $8 \%$, окислении при $950{ }^{\circ} \mathrm{C}$ в потоке воздуха в течение 10 мин и восстановлении при $1100{ }^{\circ} \mathrm{C}$ в атмосфере СО. В результате связующее МНА, извлеченное из лигнита «Baganuur», повлияло на степень восстановления сильнее, чем два других связующих в этом исследовании. Общее содержание железа в восстановленном продукте достигло 98,33 \% с $1 \%$ МНА, извлеченного из лигнита «Baganuur». Степень восстановления выражена потерей кислорода.

Ключевые слова: магнетит, связующее МНА, восстановление, брикет.

DOI: $10.17073 / 0368-0797-2020-6-419-427$

Information about the authors:

Баяра Сараатанбазар, аспирант ( s.bayar9@gma i l .com) Гуан-хуэй Ли, профессор (2667361847@qq.com)

Поступила в редакцию 9 апреля 2019 г. После доработки 15 июня 2020 г.

Принята к публикации 16 июня 2020 г. 